\title{
Late Pregnancy Allowances in Does on Haemato Biochemical Response in Kids
}

\author{
S. Sahu ${ }^{1}$, L.K. Babu ${ }^{2}$, Archana Sarangi ${ }^{3 *}$, Amit ${ }^{1}$ and D.K. Karna ${ }^{4}$ \\ ${ }^{1}$ Department of LPM, LUVAS, Hisar, Haryana, India \\ ${ }^{2}$ Department of LPM, ${ }^{4}$ Department of AGB, OUAT, Bhubaneswar, Odisha, India \\ ${ }^{3}$ Division of Animal Physiology, NDRI, Karnal, Haryana, India \\ *Corresponding author
}

\section{Keywords}

Concentrate,

Pregnancy, Doe,

Blood profile, Kids

Article Info

Accepted:

26 January 2019

Available Online:

10 February 2019

A B S T R A C T

Forty five extensively reared pregnant Ganjam does were randomly distributed into three treatment groups $\left(\mathrm{T}_{1}, \mathrm{~T}_{2}, \mathrm{~T}_{3}\right), 15$ in each for evaluating the effect of late pregnancy allowances to them on haemato-biochemical profiles of their kids. All the does were maintained on browsing besides additional concentrate supplementation@200 g/day and @ $300 \mathrm{~g} /$ day in $\mathrm{T}_{2}$ and $\mathrm{T}_{3}$, respectively. Additional allowances were fed to the treatment groups 2 months prior to the expected date of kidding. Immediate after kidding, blood samples were collected from the day old kids for analysis of hemoglobin, PCV, TEC, $\mathrm{MCV}, \mathrm{MCH}, \mathrm{MCHC}$, TLC, serum glucose, urea, total protein, albumin, globulin, A:G, cholesterol, triglyceride, urea and creatinine. The lambs in $\mathrm{T}_{2}$ and $\mathrm{T}_{3}$ showed significantly $(\mathrm{P}<0.05)$ higher haemoglobin $(\mathrm{g} / \mathrm{dl})\left(\mathrm{T}_{2}: 9.95 \pm 0.18 ; \mathrm{T}_{3}: 9.84 \pm 0.30\right)$ and PCV \% $\left(\mathrm{T}_{2}\right.$ : $\left.29.59 \pm 1.16 ; \mathrm{T}_{3}: 29.04 \pm 1.32\right)$ than those in $\mathrm{T}_{1}$ group. Other haematological parameters remained statistically similar $(\mathrm{P}>0.05)$ between groups. Significant differences $(\mathrm{P}<0.05)$ were observed for serum glucose in $\mathrm{T}_{2}(56.94 \pm 1.46 \mathrm{mg} / \mathrm{dl})$ and $\mathrm{T}_{3}(55.99 \pm 1.32 \mathrm{mg} / \mathrm{dl})$ as compared to $\mathrm{T}_{1}(49.82 \pm 2.16 \mathrm{mg} / \mathrm{dl})$.For both total protein and albumin $(\mathrm{g} / \mathrm{dl}), \mathrm{T}_{2}(8.59 \pm$ 0.06 and $4.34 \pm 0.04)$ and $\mathrm{T}_{3}(8.97 \pm 0.04$ and $4.66 \pm 0.08)$ showed significantly $(\mathrm{P}<0.05)$ higher value than $\mathrm{T}_{1}(7.15 \pm 0.04$ and $3.14 \pm 0.11)$ while serum globulin remained statistically similar between groups. Other Serum biochemical parameters were found to be non significant $(\mathrm{P}>0.05)$ among groups. It was concluded that late pregnancy allowances@200 g/day/doe in extensively reared does is required to maintain the glucose and protein level in day old kids, may help for their further growth.

\section{Introduction}

Ganjam goat sometimes called as "Golla goat' locally, is distributed in eastern region of India and specifically in the whole of
Ganjam district along with parts of Gajapati district of southern Odisha (Sahu et al., 2013). Justifying Indian goats as "poor man's cow", this breed has been a major source of livelihood of Golla tribe of its native tract 
since generations. These goats are reared under extensive system of management without any supplementary feed. Nearby range and forest land mostly serve as the feed source for these goats (Sahu et al., 2015). Nutritional inadequacy in the extensive system specifically to the pregnant does is a major challenge. Rapid rate of foetal growth during the final 6-8 weeks of pregnancy imposes a metabolic challenge to the doe which is met by the mobilisation of maternal body tissue (Osuagwuh and Aire, 1990) and this may result in weight loss of doe if the dietary supply of nutrients is inadequate (Martin et al., 2005 and Rafiq et al., 2003). An increased plane of nutrition during late gestation has been reported to have various advantages, such as; reduced incidence of pregnancy toxaemia (Fraser et al., 1938; Charismiadou et al., 2000), less metabolic stress (Kerslake et al., 2010). Some encouraging results have been obtained by many workers by prepartum supplementation (Chaturvedi et al., 2008 and Dawson et al., 2005). Besides the above benefits, maternal nutrition significantly affect the birth weight of kids (Sahu et al., 2018) which in-turn maintain proper pre-weaning growth and good health of kid. Nutrition of dam during pregnancy influences blood metabolites of kids which serve as an excellent tool for prediction of the metabolic status of animal and their future performance. Considering the above facts in mind the present study was undertaken to study the effect of late pregnancy allowances in does on haemato biochemical response in kids.

\section{Materials and Methods}

The present investigation was carried out in Chhatrapur block of Ganjam district of Orissa where AICRP on Goat Improvement (Ganjam Field Unit) is operating. These areas are dominated by 'Golla' people, who rear Ganjam goats traditionally in large number in range system. The animals selected were from the flocks of registered goat farmers of the project. For this study, pregnant does of similar body weight $(33.91 \pm 0.70 \mathrm{~kg}$ to 34.59 $\pm 0.75 \mathrm{~kg}$ ), age and parity ( $3^{\text {rd }}$ to $5^{\text {th }}$ parity) were selected. The expected dates of kidding were estimated as per the breeding history of goat given by the flock man. A total of 45 healthy pregnant does were taken for this study. The selected does were randomly allotted to three treatment groups based on complete randomized design, each compromising 15 pregnant does and kept in different feeding regimens viz. $\left(\mathrm{T}_{1}\right)$ : Control; normal browsing at range system; $\left(\mathrm{T}_{2}\right)$ : Control with daily supplementation of $200 \mathrm{~g}$ concentrate mixture and $\left(\mathrm{T}_{3}\right)$ : Control with daily supplementation of $300 \mathrm{~g}$ concentrate mixture. This concentration mixture contained $22 \%$ crude protein (estimated) with $72 \%$ Total Digestible Nutrients (calculated). Concentrate feeding was done in very early morning by confining the goats in partition wall made up of bamboo and taken to the nearby forest thereafter, for the purpose of browsing (Average duration was 8hours, from 9am to $4 \mathrm{pm}$ ) as it was a routine practice of the flock man. Concentrate feeds were offered upto parturition and average daily Dry Matter Intake (DMI) was $163 \mathrm{~g} /$ doe/day and 224.0 g/doe/day in $T_{2}$ and $T_{3}$ respectively. Immediate after kidding, blood samples were collected from the kid by jugular vein puncture before suckling.

For estimation of haematological parameters like Haemoglobin, Haematocrit (PCV), TEC, MCV, MCH, MCHC and TLC, $2 \mathrm{ml}$ blood collected in blood collection tube containing EDTA as described by Benjamin (1985). For analysis of biochemical parameters, $6 \mathrm{ml}$ blood was collected in sterilized dry centrifuge tubes and kept in slanted position at room temperature for some time and centrifugation was done at 5000rpm for 10 minutes at $4^{\circ} \mathrm{C}$. The supernatant (serum) was 
separated in airtight serum storage vials and kept at $-20^{\circ} \mathrm{C}$ till analysis of biochemical parameters. Analysis was done after thawing for various biochemical profiles (total protein, albumin, globulin, urea, creatinine, cholesterol and triglyceride) except glucose which was done soon after collection of serum, as per the standard protocol.

Data, thus obtained were subjected to suitable statistical analysis following standard methods described by Snedecor and Cochran (1994) using the SAS 9.2 package.

\section{Results and Discussion}

As a means of metabolic indicator in the new born kids and their future performance, the effect of late pregnancy allowances in does on haemato biochemical response in kids are presented in table 1 and 2. The haemoglobin level ranged from $9.01 \pm 0.21$ to $9.95 \pm 0.18 \mathrm{~g} / \mathrm{dl}$ in various treatment groups under study. Kids in $\mathrm{T}_{2}(9.95 \pm 0.18 \mathrm{~g} / \mathrm{dl})$ and $\mathrm{T}_{3}(9.84 \pm 0.30 \mathrm{~g} / \mathrm{dl})$ showed significantly $(\mathrm{P}<0.05)$ higher haemoglobin than those in $\mathrm{T}_{1}$ group $(9.01 \pm 0.21 \mathrm{~g} / \mathrm{dl})($ Table 1). Similar to the the above findings, kids under $\mathrm{T}_{1}$ group showed significantly lower PCV $(26.01 \pm 1.48 \%)$ as compared to $\mathrm{T}_{2}(29.59 \pm 1.16 \%)$ and $\mathrm{T}_{3}(29.04$ $\pm 1.32 \%$ ). For both the parameters, kids under $\mathrm{T}_{2}$ and $\mathrm{T}_{3}$ revealed statistically similar result. No significant variation was observed between groups for the other haematological parameters viz. Total Erythrocyte Count (TEC: $12.89 \pm 0.47$ to $13.12 \pm 0.39$ ), Total Leucocyte Count (TLC:7.98 \pm 0.31 to 8.19 $\pm 0.25)$, Mean Corpuscular Volume (MCV:19.41 \pm 0.89 to $20.15 \pm 0.65)$, Mean Corpuscular Haemoglobin (MCH: $8.31 \pm 0.12$ to $8.54 \pm 0.14)$ and Mean Corpuscular Haemoglobin Concentration (MCHC: $30.54 \pm$ 1.68 to $32.14 \pm 2.76$ ) (Table 1). Decreased concentration of $\mathrm{Hb}$ and $\mathrm{PCV} \%$ in kids under extensively reared groups could be due to the fact that non supplementation of the does with concentrate mixture during pregnancy limits the normal physiological function and decrease the PCV and $\mathrm{Hb}$ values in the blood of day old kids (Sahoo et al., 2016). Serum glucose level in the day old kids after 60 days of feeding trial to their dams ranged between $49.82 \pm 2.16$ to $56.94 \pm 1.46 \mathrm{mg} / \mathrm{dl}$ in the different treatment groups under study (Table 2 ). The glucose concentrations recorded in the present study is well within the normal range of 45-60 mg/dl (Altman and Dittmer, 1961) but lower than $63.35 \pm 7.70 \mathrm{mg} / \mathrm{dl}$ (Sandabe et al., 2004). This might be due to the differences in breed, environment and nutritional status of the experimental animals in the two studies.

A significantly higher value of serum glucose in $\mathrm{T}_{2}(56.94 \pm 1.46 \mathrm{mg} / \mathrm{dl})$ and $\mathrm{T}_{3}(55.99 \pm$ $1.32 \mathrm{mg} / \mathrm{dl})$ as compared with $\mathrm{T}_{1}(49.82 \pm 2.16$ $\mathrm{mg} / \mathrm{dl}$ ) might be due to the effect of concentrate supplementation resulting in production of higher amount of propionate, a gluconeogenic substrate, in the rumen fermentation resulting in elevated serum glucose as reported by Thomas et al., (1988) which somewhat compensates the extra energy required by the growing foetus, in-turn might enhance the blood glucose level in the day old kid at birth.

The average serum total protein ranged from $7.15 \pm 0.04$ to8.97 $\pm 0.04 \mathrm{~g} / \mathrm{dl}$ during the experimental period in the three treatment groups of Ganjam goats. The result of the present study was in agreement to the value of Kumar et al., (2008) and Kaushik and Bugalia (1999). These differences might be due to the effect of breed, environment and nutritional status of the experimental animals in the above studies. For both total protein and albumin $(\mathrm{g} / \mathrm{dl}), \mathrm{T}_{2}(8.59 \pm 0.06$ and $4.34 \pm$ $0.04)$ and $\mathrm{T}_{3}(8.97 \pm 0.04$ and $4.66 \pm 0.08)$ showed significantly $(\mathrm{P}<0.05)$ higher value than $\mathrm{T}_{1}(7.15 \pm 0.04$ and $3.14 \pm 0.11)$. In between two supplemented groups, $\mathrm{T}_{3}$ were found to have more value as compared to $\mathrm{T}_{2}$. 
Table.1 Effect of late pregnancy allowance of does on haematological profiles in kids

\begin{tabular}{|c|c|c|c|}
\hline Parameters & $\mathbf{T}_{1}$ & $\mathbf{T}_{2}$ & $\mathbf{T}_{\mathbf{3}}$ \\
\hline Haemoglobin (g/dl) & $9.01 \pm 0.21^{\mathbf{B}}$ & $9.95 \pm 0.18^{\mathbf{A}}$ & $9.84 \pm 0.30^{\mathbf{A}}$ \\
\hline Packed Cell Volume (\%) & $26.01 \pm 1.48^{\mathbf{B}}$ & $29.59 \pm 1.16^{\mathrm{A}}$ & $29.04 \pm 1.32^{\mathbf{A}}$ \\
\hline Total Erythrocyte Count $\left(10^{6} / \mu \mathrm{l}\right)$ & $13.12 \pm 0.39$ & $12.89 \pm 0.47$ & $12.91 \pm 0.51$ \\
\hline Total Leucocyte Count $\left(10^{3} / \mu \mathrm{l}\right)$ & $8.07 \pm 0.18$ & $7.98 \pm 0.31$ & $8.19 \pm 0.25$ \\
\hline Mean Corpuscular Volume (fL) & $19.4 \pm 0.89$ & $20.15 \pm 0.65$ & $19.87 \pm 1.04$ \\
\hline Mean Corpuscular Haemoglobin (pg) & $8.54 \pm 0.14$ & $8.32 \pm 0.38$ & $8.31 \pm 0.12$ \\
\hline $\begin{array}{l}\text { Mean Corpuscular Haemoglobin } \\
\text { Concentration (g/dl) }\end{array}$ & $31.80 \pm 2.10$ & $30.54 \pm 1.68$ & $32.14 \pm 2.76$ \\
\hline
\end{tabular}

Means with different superscripts in a row $(\mathrm{A}, \mathrm{B})$ differ significantly $(\mathrm{P}<0.05)$.

Table.2 Effect of late pregnancy allowance of does on blood biochemical profiles in kids

\begin{tabular}{|l|c|c|c|}
\hline Parameters & $\mathbf{T}_{\mathbf{1}}$ & $\mathbf{T}_{\mathbf{2}}$ & $\mathbf{T}_{\mathbf{3}}$ \\
\hline Glucose (mg/dl) & $49.82 \pm 2.16^{\mathbf{B}}$ & $56.94 \pm 1.46^{\mathbf{A}}$ & $55.99 \pm 1.32^{\mathbf{A}}$ \\
\hline Total Protein (g/dl) & $7.15 \pm 0.04^{\mathbf{C}}$ & $8.59 \pm 0.06^{\mathbf{B}}$ & $8.97 \pm 0.04^{\mathbf{A}}$ \\
\hline Albumin (g/dl) & $3.14 \pm 0.11^{\mathbf{C}}$ & $4.34 \pm 0.04^{\mathbf{B}}$ & $4.66 \pm 0.08^{\mathbf{A}}$ \\
\hline Globulin (g/dl) & $4.02 \pm 0.16$ & $4.25 \pm 0.09$ & $4.31 \pm 0.21$ \\
\hline A/G ratio & $0.78 \pm 0.05^{\mathbf{B}}$ & $1.02 \pm 0.03^{\mathbf{A}}$ & $1.08 \pm 0.07^{\mathbf{A}}$ \\
\hline Urea (mg/dl) & $23.98 \pm 1.58$ & $25.18 \pm 0.95$ & $24.91 \pm 1.36$ \\
\hline Creatinine (mg/dl) & $0.61 \pm 0.03$ & $0.59 \pm 0.05$ & $0.65 \pm 0.03$ \\
\hline Cholesterol (mg/dl) & $72.45 \pm 3.58$ & $69.94 \pm 5.08$ & $70.76 \pm 3.97$ \\
\hline Triglyceride (mg/dl) & $33.57 \pm 2.11$ & $34.81 \pm 2.95$ & $31.79 \pm 3.08$ \\
\hline
\end{tabular}

Means with different superscripts in a row $(\mathrm{A}, \mathrm{B}, \mathrm{C})$ differ significantly $(\mathrm{P}<0.05)$.

Significantly higher total protein concentrations were observed in kids of supplemented ewes suggesting that improved nutritional status in $\mathrm{T}_{2}$ and $\mathrm{T}_{3}$ does (Sahoo et al., 2016) might have resulted in more nutrients availability for the foetus in turn in day old kids. Contrary to the above protein parameters, serum globulin concentration (g/dl) was statistically similar $(\mathrm{P}>0.05)$ in $\mathrm{T}_{1}$ $(4.02 \pm 0.16), \mathrm{T}_{2}(4.25 \pm 0.09)$ and $\mathrm{T}_{3}(4.31 \pm$
0.21), however it remained within the normal physiological range. Non significant difference in serum globulin concentration in different groups might be due to inability of the immunoglobul into cross the placental barrier (Castro et al., 2011). The mean serum $\mathrm{A} / \mathrm{G}$ ratio was statistically higher $(\mathrm{P}<0.05)$ in $\mathrm{T}_{2}(1.02 \pm 0.03)$ and $\mathrm{T}_{3}(1.08 \pm 0.07)$ as compared to $\mathrm{T}_{1}(0.78 \pm 0.05)$. Significant difference in $A / G$ ration is due to a significant 
increase in albumin concentration in supplemented groups as compared to non supplemented groups. The values for other serum biochemical values (Table 2) viz. urea $\left(23.98 \pm 1.58\right.$ in $\mathrm{T}_{1}$ to $25.18 \pm 0.95 \mathrm{mg} / \mathrm{dl}$ in $\left.\mathrm{T}_{2}\right)$, creatinine $\left(0.59 \pm 0.05\right.$ in $\mathrm{T}_{2}$ to $0.65 \pm 0.03$ $\mathrm{mg} / \mathrm{dl}$ in $\left.\mathrm{T}_{3}\right)$, cholesterol $\left(69.94 \pm 5.08\right.$ in $\mathrm{T}_{2}$ to $72.45 \pm 3.58 \mathrm{mg} / \mathrm{dl}$ in $\mathrm{T}_{1}$ ) and triglyceride $\left(31.79 \pm 3.08\right.$ in $\mathrm{T}_{3}$ to $\left.34.81 \pm 2.95 \mathrm{mg} / \mathrm{dl}_{2}\right) \mathrm{did}$ not show any significant difference $(\mathrm{P}>0.05)$ between the groups, but were in line with standard values of the available literature.

It can be concluded that an extra allowances of concentrate @200g/day/doe besides normal browsing to the pregnant doe improved birth weight and metabolic profile of kids.

\section{Acknowledgement}

Authors are highly thankful to Vice Chancellor and OIC, AICRP on Goat Improvement, O.U.A.T., Bhubaneswar for providing all the facilities to carry out this research work at Ganjam, Odisha, India.

\section{References}

Altman, P.L., and Dittmer, D.S. 1961. Blood and other body fluids. $1^{\text {st }}$ edition, Fed. Am. Soc. Exp. Biol., Washington.

Castro, N., Capote, J., Bruckmaier, R.M. and Argüello, A. 2011. Management effects on colostrogenesis in small ruminants: a review. J. Applied Anim. Res., 39:2, 8593 ,

DOI: 10.1080/09712119.2011.581625.

Charismiadou, M.A., Bizelis, J.A. and Rogdakis, E. 2000. Metabolic changes during the perinatal period in dairy sheep in relation to level of nutrition and breed. I. Late pregnancy. J Anim. Physiol. Anim. Nutr., 84(3-4): 61-72.

Chaturvedi, O.H., Verma, D.L., Singh, N.P. and Man, J.S. 2008. Effect of concentrate supplementation on production performance of ewes grazing on community rangeland. Indian $J$. Anim. Sci., 78(10): 1162.

Dawson, E.R., Carson, A.F., Kilpatrick, D.J. and Laidlaw, A.S. 2005. Effect of herbage allowance and concentrate food level offered to ewes in late pregnancy on ewe and lamb performance. Brit. Soc. Anim. Sci., 81: 413.

Fraser, A.H.H., Godden, W., Snook, L.C. and Thomson, W. 1938. The influence of diet upon ketonaemia in pregnant ewes. J., Physiology., 94: 346-357.

Ingvartsen, K.L. 2006. Feeding and management related diseases in the transition cow. Physiological adaptions around calving and strategies to reduce feeding-related diseases. Anim. Feed Sci. Techno., 126: 175-213.

Kaushik, H.K. and Bugalia, N.S. 1999.Plasma total protein, cholesterol, minerals and transminases during pregnancy in goats. Indian Vet. J. 76: 603-606

Kerslake, J.I., Kenyon, P.R., Morris, S.T., Stafford, K.J. and Morel, P.C.H. 2010. Does offering concentrate supplement during late pregnancy affect twin- and triplet- bearing ewe and lamb performance? New Zeal J. Agr. Res., 53(4): $315-325$.

Kumar. P., Roy, N. and Mishra, S.N. 2008. Studies on changes in haematobiochemical values under different physiological stresses of goats. Royal Vet.J.India.4: 53-56

Martin, G.B., Rodger, J. and Balache, D. 2005. Nutritional and environmental effect on reproduction in small ruminants. Repro.fertility Dev.16: 491501.

Osuagwuh, A.I.A. and Aire, T.A. (1990). Intra uterine growth rates of the West Africa an dwarf goats and some fetal organs in relation to strategic feed supplementation during pregnancy. $J$. Vet. Med., 37: 198. 
Rafiq, M., Khan, M.F. and Aujla, K.M. (2003). Economic benefits of lushing and supplemental feeding of salt-range ewes on pothwar ranges of Pakistan. Pakistan J. Biol. Sci., 6: 115.

Sahoo, C., Pradhan, C.R., Sahu, S., Kumari, A. and Sarangi, A. 2016. Growth and haemato-biochemical response in lambs in relation to supplementary feeding of ewes in late pregnancy. Ind. J. small Rumin., 22 (2): 249-251.

Sahu, S., Babu, L.K., Karna, D.K., Behara, K., Kanungo, S., Kamal, R. and Upadhyay, D. 2015. Effect of prepartum supplementation on blood biochemical profiles of pregnant Ganjam goats. Indian J. Anim. Res., 49 (4): 487-490.

Sahu, S., Babu, L.K., Karna, D.K., Behara, K., Kanungo, S., Kaswan, S., Biswas, P. and Patra, J.K. 2013. Effect of different level of concentrate supplementation on the periparturient growth performance of Ganjam goats in extensive
system.Vet. World, 6 (7): 428-432.

Sahu, S., Babu, L.K., Sarangi, A., Ajithakumar, H.M. and Karna, D.K.2018. Effect of steaming-up on the growth performance of kids and economics in extensive rearing system. Haryana Vet., 57 (1): 80-82.

Sandabe, U.K., Mustapha, A.R. and Sambo, E.Y. 2004. Effect of pregnancy on some biochemical parameters in Sahel goats in semi arid zones. Vet. Res. Comm.,28: 279-285.

Snedecor, G.W. and Cochran, W.G. 1994. Statistical methods. $8^{\text {th }}$ edition. Iowa State University Press, Ames, Iowa.

Thomas, V.M., McInerny, M.J. and Kott, R.W. 1988. Influence of body conditions and lasolacid during late gestation on blood metabolites, lamb birth weight, colostrums consumption and production in Finn cross ewes. $J$. Anim. Sci. 66: 1183-1191.

\section{How to cite this article:}

Sahu, S., L.K. Babu, Archana Sarangi, Amit and Karna, D.K. 2019. Late Pregnancy Allowances in Does on Haemato Biochemical Response in Kids. Int.J.Curr.Microbiol.App.Sci. 8(02): 3416-3421. doi: https://doi.org/10.20546/ijcmas.2019.802.398 